Ks. Jerzy DUDA*

\title{
RADOŚĆ Z NAWRÓCONEGO GRZESZNIKA. METANOIA W NAUCZANIU ORYGENESA
}

Imię Orygenesa i jego teologia do dnia dzisiejszego wzbudza w świecie naukowym wiele emocji i kontrowersji. Dla jednych jest on geniuszem myśli chrześcijańskiej, dla innych heretykiem. Jednakże, niezależnie od polemik, większość badaczy wczesnego Kościoła przyznaje, iż jego nauczanie jest kamieniem milowym i punktem odniesienia w rozwoju myśli teologicznej ${ }^{1}$. Wśród głównych osiągnięć Adamantiosa („Człowieka ze stali”) podkreśla się podjętą próbę usystematyzowania doktryny chrześcijańskiej, jak również metodyczną egzegezę prawie wszystkich Ksiag Starego i Nowego Testamentu, w oparciu o wypracowane kryteria poszukiwania ,prawdy Ewangelii”.

W niniejszej pracy podejmiemy próbę rekonstrukcji i analizy Orygenesowej koncepcji metanoi w kontekście pochodzącej z 15. rozdziału Ewangelii według św. Łukasza przypowieści „o zagubionej owcy” oraz podsumowujących ją słów Jezusa mówiących, iż

„W niebie większa będzie radość $\mathrm{z}$ jednego grzesznika, który się nawraca, niż z dziewięćdziesięciu dziewięciu sprawiedliwych, którzy nie potrzebują nawrócenia" (Łk 15, 7).

Do dnia dzisiejszego przypowieść o zaginionej owcy należy do klasycznych obrazów w przedstawianiu przez Kościół nauki o Bożym miłosierdziu, nawróceniu i wynikających z niego konsekwencjach. Interesujące więc wydaje się sięgnięcie do źródeł chrześcijaństwa i przybliżenie nauki na ten temat jednego z najwybitniejszych teologów wczesnego Kościoła, tym bardziej, iż wygłoszone przez Orygenesa Homilie o Ewangelii św. Lukasza są najstarszą interpretacją tej księgi w historii chrześcijańskiej egzegezy.

Analiza pism Orygenesa nastręcza wiele trudności. W tym przypadku jedną z najważniejszych jest tekst źródłowy badanego dzieła. Niestety, poza fragmentami, zaginął oryginał w języku greckim. Nie dotarł też do naszych czasów

${ }^{*}$ Ks. dr Jerzy Duda - adiunkt w Katedrze Teologii Patrystycznej w Instytucie Teologii Systematycznej na Wydziale Teologicznym Uniwersytetu Kard. Stefana Wyszyńskiego w Warszawie; e-mail: jerzy.duda@onet.eu.

${ }^{1}$ Por. M. Starowieyski, Mariologia Orygenesa (wstęp), w: Orygenes, Homilie o Ewangelii św. Łukasza, PSP 36, Warszawa 1986, 27. 
istniejący jeszcze za czasów Hieronima Komentarz do Ewangelii św. Łukasza². Chociaż przetrwał przetłumaczony na łacinę przez Translatora ze Strydonu tom Homiliae in Lucam, to jednak brakuje w nim całościowego komentarza do badanego przez nas fragmentu, zaś odnośniki do niego w innych homiliach Orygenesa są nieliczne. Wartość egzegetyczno-teologiczna Łk 15, 4-7 wydaje się na tyle ważna, iż możemy założyć, że Adamantios przeprowadził odpowiedni i być może nawet szczegółowy komentarz badanej przez nas perykopy, jednak zaginął on prawdopodobnie w wyniku sporów orygenesowskich. W związku z tym konieczne było zebranie poszczególnych wypowiedzi Orygenesa przedstawionych obiter oraz sięgnięcie do innych jego dzieł, by wyłuskać z nich interesującą nas problematykę. Przeprowadzona przez nas szczegółowa analiza doprowadziła do dość ciekawych wniosków. Mimo, iż Scholarcha z Aleksandrii zasłynął jako niezrównany mistrz egzegezy duchowej i alegorycznej, zakładającej niezwykłe bogactwo znaczeń każdego występującego w Biblii tekstu czy nawet słowa, to jednak w interesującym nas przypadku daje się zauważyć pewną niekonsekwencję oraz powtarzające się myśli.

Bez watpienia u podstaw analizowanego przez nas komentarza do przypowieści o nawróceniu i płynącej z tego faktu radości leży powiązanie jej przez Orygenesa z szeroko rozumianą hipotezą apokatastazy. Jednym z podstawowych tekstów traktujących o ostatecznej szczęśliwości zbawionych zjednoczonych $\mathrm{w}$ radości z Bogiem, uzależnionej od wcześniejszego nawrócenia i pokuty tych, którzy jeszcze są na ziemi, jest klasyczny fragment siódmej homilii do Księgi Kapłańskiej:

\begin{abstract}
„Zbawiciel mój wciąż jeszcze opłakuje moje grzechy. Zbawiciel mój nie może się radować, dopóki ja trwam w niegodziwości [...]. Czeka zatem, abyśmy się nawrócili, abyśmy naśladowali Jego przykład, abyśmy poszli w Jego ślady, iżby mógł się radować razem z nami [...]. Cóż zatem? Oczekuje radości. Kiedy jej oczekuje? Powiada: «Gdy wykonam dzieło Twoje». Kiedy «wypełnia to dzieło»? Wypełni dzieło wówczas, gdy mnie, ostatniego i najgorszego ze wszystkich grzesznika uczyni pełnym i doskonałym. Teraz więc dzieło jego jest niedoskonałe, dopóki ja jeszcze jestem niedoskonały. Dopóki wreszcie ja nie jestem «poddany» Ojcu, dopóty i On nie jest «poddany» Ojcu [...]. Otóż również i apostołowie nie dostapili jeszcze swojej radości, lecz oni także czekają, abym i ja stał się uczestnikiem ich wesela. Wszak święci, odchodząc z tego świata, nie otrzymują natychmiast pełnej zapłaty za swoje zasługi; oni czekają na nas, chociaż my zwlekamy, choć my jesteśmy opieszali. Nie mają więc i oni pełnej radości, dopóki boleją nad naszymi błędami i opłakują nasze grzechy"3.
\end{abstract}

${ }^{2}$ Por. Origenes, In Lucam hom., Prolog, ed. H. Crouzel - F. Fournier - P. Périchon, SCh 87, 93, thum. S. Kalinkowski: Orygenes, Homilie o Ewangelii św. Łukasza, PSP 36, Warszawa 1986, 31.

${ }^{3}$ Tenże, In Leviticum hom. 7, 2, ed. M. Borret, SCh 286, 308-316: „Salvator meus luget etiam nunc peccata mea. Salvator meus laetari non potest, donec ego in iniquitate permaneo [...]. Exspec- 
Nie jest zamierzeniem niniejszej publikacji szczegółowe prezentowanie tematyki związanej z apokatastaza, zresztą posiadającej bogatą literaturę przedmiotu $^{4}$, jednakże warto zwrócić uwagę na te jej elementy, które pojawiają się $\mathrm{w}$ interpretacji interesującej nas przypowieści jako niewątpliwa konsekwencja przyjętych przez Scholarchę z Aleksandrii założeń stworzonego przez niego tzw. ,systemu" teologicznego ${ }^{5}$.

Przytoczony powyżej fragment Homilii do Księgi Kapłańskiej rzuca interesujące światło na Orygenesową koncepcję eschatologicznej soteriologii. Adamantios zakładał, iż stan szczęścia społeczności świętych w niebie nie jest jeszcze doskonały. Radość wieczna ma bowiem charakter wspólnotowy i urzeczywistni się w pełni, gdy wszyscy oddaleni od Boga przez grzech wejdą na drogę nawrócenia oraz upodobnienia się do Tego, który jest obrazem Boga niewidzialnego, to jest Chrystusa. Upodobnienie i naśladowanie należą do podstawowych pojęć w teologii duchowości Orygenesa. Droga ta ma doprowadzić ich do stanu poddania Ojcu. Stwierdzenie mówiące o zjednoczeniu człowieka grzesznego z Bogiem przez proces zmierzający do ostatecznego wypełnienia dzieła zbawienia nawiązuje do nauki św. Pawła zawartej w Liście do Koryntian ${ }^{6}$. Tekst Pawłowy należy do fundamentalnych fragmentów biblijnych wykorzystanych przez Scholarchę z Aleksandrii do

tat ergo, ut convertamur, ut ipsius imitemur exemplum, ut sequamur vestigia eius et laetetur nobis cum [...]. Quid ergo est? Exspectat laetitiam. Quando exspectat? «Cum consummavero», inquit, «opus tuum». Quando «consummat» hoc «opus»? Quando me, qui sum ultimus et nequior omnium peccatorum, consummatum fecerit et perfectum, tunc «consummat opus eius»; nunc enim adhuc imperfectum est opus eius, donec ego maneo imperfectus. Denique donec ego non sum subditus patri, nec ipse dicitur patri esse «subiectus». [...] Nondum enim receperunt laetitiam suam ne Apostoli quidem, sed et ipsi exspectant, ut et ego laetitiae eorum particeps fiam. Neque enim discedentes hinc sancti continuo integra meritorum suorum praemia consequuntur; sed exspectant etiam nos, licet morantes, licet desides. Non enim est illis perfecta laetitia, donec pro erroribus nostris dolent et lugent nostra peccata", thum. S. Kalinkowski: Orygenes, Homilie o Księdze Kapłańskiej, PSP 31/2, Warszawa 1984, 86-88.

${ }^{4}$ Por. H. Crouzel, L'apocatastase chez Origène, w: Origeniana Quarta. Referate des 4. Internazionalen Origeneskongress (Innsbruck, 2-6 September), hrsg. von L. Lies, Innsbrucker Theologische Studien 19, Innsbruck 1987, 282-290; E. Prinzivalli, Apocatastasi, w: Origene. Dizionari: la cultura, il pensiero, le opere, ed. A. Monaci-Castagno, Roma 2000, 24; H. Cornélis, Les fondements cosmologiques de l'eschatologie d'Origène, RSPT 43 (1959) 32-80 i 201-247; G. Müller, Origenes

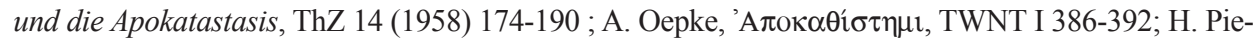
tras, Apokatastasis wedlug Ojców Kościoła. Nadzieja nawrócenia czy powszechna amnestia?, CT 62 (1992) z. 3, 21-41; W. Szczerba, Koncepcja wiecznego powrotu w myśli wczesnochrześcijańskiej, Wrocław 2001; J. Duda, Jeden świat czy wiele światów? Kosmologiczne podstawy doktryny Orygenesa, Siedlce 2008, 144-161.

${ }^{5}$ Por. H. Crouzel, Orygenes, thum. J. Margański, Kraków 2004, 321-322.

${ }^{6}$ Por. 1Kor 15, 27-28: „Wszystko bowiem rzucił pod stopy Jego. Kiedy się mówi, że wszystko jest poddane, znaczy to, że z wyjątkiem Tego, który Mu wszystko poddał. A gdy już wszystko zostanie Mu poddane, wtedy i sam Syn zostanie poddany Temu, który Synowi poddał wszystko, aby Bóg był wszystkim we wszystkich". 
wyartykułowania przez niego hipotezy apokatastazy. Orygenes, głosząc ideę nadziei na ostateczny powrót do jedności z Bogiem upadłych w grzech istot inteligibilnych, podkreśla wzajemną komunię oraz solidarność wszystkich istot rozumnych $\mathrm{w}$ procesie nawrócenia ${ }^{7}$. Akt ten może urzeczywistnić się tylko dzięki zbawczej interwencji Chrystusa, który przez swoje wcielenie i dzieło odkupienia pojednał w sobie upadłe stworzenie. Orygenes odwołuje się do obrazu społeczności odkupionych stanowiących jedno ciało, którego głową jest Syn Boży ${ }^{8}$. Do tej pory nie doświadcza ono pełni radości i szczęścia, gdyż dzieło Chrystusa nie zostało jeszcze zakończone. Dopóki bowiem chociażby jeden z członków ciała nie będzie w pełni poddany Bogu, w Chrystusie i przez Chrystusa, dopóty i On sam nie będzie doznawał doskonałej radości i chwały. Sama bowiem świadomość, że Jego ciału brakuje jakiegoś członka, bądź przez grzech ktoś należy do Niego jedynie częściowo, rodzi w Chrystusie smutek. Antropomorficzny obraz Syna Bożego opłakującego grzech człowieka nawiązuje do Jego zbawczej funkcji rzecznika wobec Ojca, który wziął na siebie wszystkie niegodziwości, by za nie złożyć na krzyżu ofiarę przebłagalną. Płacz Chrystusa nad człowiekiem i jego upadkiem jest obrazem współczucia, ale też wstawiennictwa. Dopóki więc całe stworzenie nie zostanie w pełni doprowadzone do doskonałej jedności w niebie, Syn Boży będzie czekał, a wraz z nim wszyscy święci i aniołowie. Nie będzie to jednak proces bierny. Bóg bowiem ciagle w Chrystusie pochyla się ku człowiekowi, by ten się nawrócił i naśladując Jego przykład poszedł w Jego ślady ${ }^{9}$. Orygenes nie ogranicza zbawczego działania Boga jedynie do naszego świata i obecnego czasu. Bóg w swoim miłosierdziu może dać szansę, by proces pełnego poddania kontynuować po śmierci zarówno w tzw. „szkole dusz"10, jak też w przyjmowanych hipotetycznie kolejnych światach czy wiekach następujących po naszym ${ }^{11}$.

Ślady odzwierciedlenia takiej koncepcji odnajdujemy w omawianej przypowieści. Według Adamantiosa ten, który zwie się „Synem Miłości” (Kol 1, $13)^{12}$, który jako Boski Lekarz pochylał się nad ludźmi cierpiącymi i poranionymi przez grzech, który płakał na Jerozolimą, również i teraz wstawia się za człowiekiem, pochyla się nad jego ranami i szuka tych, którzy zginęli ${ }^{13}$. W takim właśnie kontekście najczęściej interpretuje Orygenes przypowieści o miłosierdziu Boga i radości płynącej z nawrócenia grzesznika. Bez wątpienia sta-

\footnotetext{
${ }^{7}$ Por. Duda, Jeden świat, s. 201.

${ }^{8}$ Por. Origenes, In Leviticum hom. 7, 2, SCh 286, 310-314, PSP 31/2, 86-88.

${ }^{9}$ Por. tamże.

${ }^{10}$ Por. tenże, De principiis II 11, 3-4, ed. H. Crouzel - M. Simonetti, SCh 252, 399-402, thum. S. Kalinkowski: Orygenes, O zasadach, ŹMT 1, Kraków 1996, 216-217; zob. Crouzel, Orygenes,

${ }^{11}$ Por. Origenes, De principiis II 3, 4-5, SCh 252, 259-262, ŹMT 1, 151-152.

${ }^{12}$ Por. tenże, In Leviticum hom. 7, 2, SCh 286, 310, PSP 31/2, 86.

${ }^{13}$ Por. tamże.
} s. 300-301. 
nowiły one dla Scholarchy z Aleksandrii doskonały obraz dla przedstawienia nauki o upadku w grzech, nadziei powszechnego zbawienia i ostatecznej rzeczywistości chwały. W dalszej części artykułu, odwołując się do przykładów z przypowieści „o zagubionej owcy”, postaramy się pokazać w jej egzegezie dokonanej przez Orygenesa wyszczególnione powyżej elementy.

\section{PRZYPOWIEŚĆ O ZAGUBIONEJ OWCY}

Pierwszą z przypowieści o nawróceniu i Bożym miłosierdziu, występujących w 15. rozdziale Ewangelii Łukasza, jest opowiadanie o zagubionej owcy. Przystępując do analizy Orygenesowego komentarza do tej perykopy należy zauważyć, iż Scholarcha wykorzystał w nim w całej rozciagłości opracowane przez siebie metodologiczne zasady dotyczące interpretacji Biblii, a w szczególności egzegezę alegoryczną oraz chrystocentryzm. Według niego całe Pismo Święte jest ukierunkowane ku Chrystusowi, który stoi za każdym jego słowem. Chrystus bowiem jest objawieniem Ojca, Logosem, Jego Słowem, które odsłania w sobie Bożą rzeczywistość. Każde więc słowo w Biblii ma odniesienie do Chrystusa, który niejako „wcielił się” w tekst ${ }^{14}$. Dlatego w słowie Pisma tkwi wielka tajemnica, moc i bogactwo znaczeń, podobnie jak wielkim misterium jest dla człowieka sam Bóg. Mając na uwadze tę regułę wyraźnie dostrzegamy, iż postacią centralną w interesującej nas przypowieści jest pasterz i jego dzieło. To w osobie Chrystusa Bóg schyla się ku człowiekowi, by na nowo otworzyć przed nim świat, który zagubił. Przypowieść jako gatunek literacki stanowiła dla Adamantiosa doskonały fundament do zastosowania w komentarzu interpretacji zarówno moralnej, jak i duchowej, co postaramy się poniżej wykazać.

Orygenes najczęściej analizował tę przypowieść w kontekście historiozbawczym i eschatologicznym. Pisząc w Contra Celsum o ostatecznym przeznaczeniu duszy do życia wiecznego stwierdza, iż Bóg okazał swoje miłosierdzie względem człowieka, gdy sam zstąpił na ziemię, by jak pasterz odnaleźć owce należące do domu izraelskiego, które poginęły ${ }^{15}$. Adamantios mówi, iż Pismo Święte w swoim misteryjnym przekazie określa upadek w grzech jako proces zejścia owiec z gór. Do nich to zstępuje Dobry Pasterz, by je odnaleźć. $\mathrm{Z}$ miłości do zagubionych jest w stanie zostawić na miejscu te, które się nie zabłąkały. W komentarzu tym odnajdujemy echa hipotezy pierwotnego upadku w preegzystencji oraz jednoczącej apokatastazy. Zagubiona owca z Jezusowej przypowieści symbolizuje całą społeczność istot inteligibilnych, które „zeszły z gór" rzeczywistości Boga. Według Adamantiosa byty rozumne stanowiły podstawę boskiego stworzenia i tworzyły pierwotny „Kościół preegzystencji”,

\footnotetext{
${ }^{14}$ Por. Crouzel, Orygenes, s. 102-119.

${ }^{15}$ Por. Origenes, Contra Celsum IV 17, ed. M. Borret, SCh 136, 222-224, thum. S. Kalinkowski: Orygenes, Przeciw Celsusowi, Warszawa 1986², 194.
} 
doskonałą wspólnotę z Logosem, jak Oblubienica z Oblubieńcem ${ }^{16}$. Byty inteligibilne zatopione w ,ogniu” Bożej miłości kontemplowały Jego wspaniałość i chwałę, co było dla nich źródłem radości i szczęścia. Radość zatem jest trwałą cechą życia niebiańskiego. Pierwotny upadek w preegzystencji, spowodowany znużeniem czy też oziębnięciem w miłości, spowodował rozpad tego świata, rozproszenie oraz zaistniałą od tej pory gradację bytów ${ }^{17}$. Bóg stworzył dla upadłego stworzenia światy najbardziej odpowiadające jego kondycji moralnej. Do takiej naznaczonej piętnem odejścia od Boga rzeczywistości schodzi Dobry Pasterz. Zostawia w niebie dziewięćdziesiąt dziewięć owiec, które były przy Nim w wiecznie istniejącym świecie chwały, i zstępuje ku tym, które upadły, nie tylko po to, by je odnaleźć, lecz by odnalezione wziąć na swe ramiona i z powrotem zanieść do nieba, gdzie jest ich miejsce ${ }^{18}$. Powrót do pierwotnej wspólnoty będzie zarówno dla istot upadłych w grzech, jak też i dla tych, które wytrwały w Bożej miłości, źródłem doskonałej radości. Dla Orygenesa taki koniec jest odzwierciedleniem istniejącego pierwotnego porządku, który będzie polegał na ostatecznym poddaniu całego stworzenia Bogu przez Chrystusa. W tym kontekście należy rozumieć słowa Jezusa, które padają w tej przypowieści, iż:

„W niebie większa będzie radość z jednego grzesznika, który się nawraca, niż z dziewięćdziesięciu dziewięciu sprawiedliwych, którzy nie potrzebują nawrócenia" (Łk 15, 7).

Stosowana przez Scholarchę egzegeza alegoryczna otworzyła przez nim możliwości skomentowania tej przypowieści również na poziomie moralnym i duchowym. W tym kontekście historia pasterza poszukującego zagubionej owcy jest odniesiona do Chrystusa i dokonanego przez Nego dzieła odkupienia, przez które została złamana moc szatana i jego władza nad człowiekiem. Wcielenie Syna Bożego, Jego śmierć i zmartwychwstanie stały się dla człowieka źródłem siły i łaski do walki ze złem, powstania z upadku i oczyszczenia z grzechu. Owca powracająca do owczarni to obraz człowieka, który wchodzi na drogę metanoi. Żyjąc na ziemi jest on już zanurzony w rzeczywistości nieba, zaś jego postęp na drodze poznawania Boga oraz upodabniania się do Niego w cnotach i dobrych uczynkach jest źródłem radości zarówno dla niego samego, jak też dla całej społeczności zbawionych ${ }^{19}$. Ze świadomości prawdy o Bogu poszukującym człowieka i wyprowadzającym go z jego zagubienia w grzechu wynika późniejsza postawa wdzięczności, przejawiająca się w modlitwie. Ona również staje się wyrazem jedności,

\footnotetext{
${ }^{16}$ Por. Crouzel, Orygenes, s. 254-255.

${ }^{17}$ Por. tamże, s. 253-268.

${ }^{18}$ Por. Origenes, In Iesu Nave hom. 7, 6, ed. A. Jaubert, SCh 71, 208-214, thum. S. Kalinkowski: Orygenes, Homilie o Księdze Jozuego, PSP 34/2, Warszawa 1986, 42-43.

${ }^{19}$ Por. tenże, In Numeros hom. 23, 2, ed. L. Doutreleau, SCh 461, 108-116, thum. S. Kalinkowski: Orygenes, Homilie o Księdze Liczb, PSP 34/1, Warszawa 1986, 223-225.
} 
z której płynie radość. W niej jednoczy się nawrócony człowiek zarówno ze swoim Pasterzem - Arcykapłanem, jak i z aniołami w niebie cieszącymi się $\mathrm{z}$ jego powrotu ${ }^{20}$.

\section{METANOIA ŹRÓDŁEM RADOŚCI}

Mimo chrystocentryzmu w przypowieści „o zagubionej owcy”, przejawiającego się w Bożym działaniu, Orygenes zwraca uwagę na osobiste zaangażowanie człowieka w proces powrotu do jedności ze Stwórca, którego oznaką jest nawrócenie, określane przez nas jako metanoia. W dalszej części pracy podejmiemy próbę analizy tego terminu nie tyle z punku widzenia filologicznego i jego wartości semantycznej, co raczej traktując go jako kategorię teologiczną.

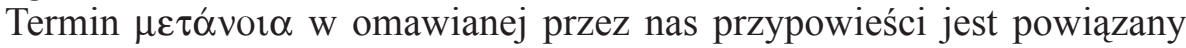
bezpośrednio z terminem $\chi \alpha \rho \alpha ́$ oznaczającym radość, $\mathrm{w}$ tym przypadku aniołów, wynikająca $\mathrm{z}$ nawrócenia grzesznika. Trudno dzisiaj w języku polskim podać jednoznacznie odpowiednik greckiego rzeczownika $\mu \varepsilon \tau \alpha ́ v v o r \alpha$. Słowniki greki klasycznej czy też specjalistyczne dotyczące greki biblijnej łączą go z czasownikiem $\mu \varepsilon \tau \alpha \nu o \varepsilon ́ \omega$ i thumaczą na poziomie etymologicznym ( $\mu \varepsilon \tau \alpha$ vov̂s) jako: zmiana myślenia, przemyślenie po zaistniałym zdarzeniu, odwrócenie myśli, zmiana wewnętrznego usposobienia, oraz na poziomie religijno-moralnym jako: żal, skrucha, pokuta, nawrócenie się z czegoś, odwrócenie się od czegoś i zwrócenie ku czemuś ${ }^{21}$. Żaden jednak z polskich terminów

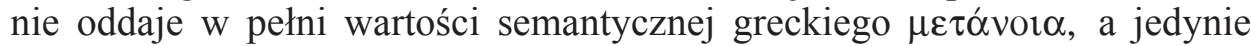
pewien aspekt jego znaczenia. Rzeczownik ten jest znaczeniowo pokrewny innemu terminowi biblijnemu, a mianowicie $\dot{\varepsilon} \pi \_\tau \rho \circ \varphi \eta$, który najczęściej

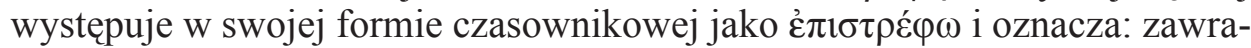
canie, powracanie, nawrócenie, zmianę przekonań, skierowanie się ku komuś, zmianę kursu, żal. Chociaż na język polski zarówno termin $\mu \varepsilon \tau \alpha v o \varepsilon ́ \omega$, jak

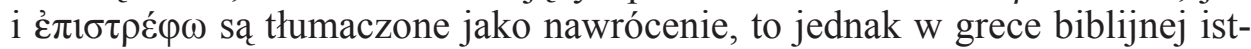

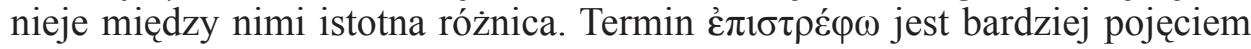
ogólnym, mówiącym o zmianie orientacji życiowej i powrocie do Boga, zaś $\mu \varepsilon \tau \alpha$ vó́ $\omega$ wskazuje bardziej na wewnętrzno-duchową postawę człowieka i jest związany ze sferą intelektualną, wolitywną i uczuciową, w których dochodzi do metamorfozy i zmiany orientacji życiowej i religijnej ${ }^{22}$. W pismach Orygenesa występują oba te terminy, zarówno w cytatach z Biblii, jak też

${ }^{20}$ Por. tenże, De oratione 11, 1, ed. P. Koetschau, GCS 3, 321, thum. W. Kania - H. Pietras, w: Odpowiedź na Stowo. Najstarsi mistrzowie chrześcijańskiej modlitwy, Kraków 1993, 132-133.

${ }^{21}$ Por. Abramowiczówna III 124, R. Popowski, Wielki słownik grecko-polski Nowego Testamentu, Warszawa 1995, 391.

${ }^{22}$ Por. H. Pelc, Wezwanie do metanoi w mowach Piotra wedlug Dziejów Apostolskich, Kraków 2004, 39-40; T. Dąbek, ,,Nawracajcie się!” Metanoia w Nowym Testamencie, Katowice 1996, 246-248. 
w jego własnych komentarzach. Jednakże trudno jest jednoznacznie rozróżnić ich wartość znaczeniową. Wiąże się to z zaginięciem wielu dzieł Adamantiosa oraz faktem przetrwania jedynie niektórych tłumaczeń. Wydaje się, iż Scholarcha z Aleksandrii stosował powyższe terminy synonimicznie. Dlatego też zwrócimy większą uwagę na metanoię jako kategorię teologiczną, określającą proces nawrócenia.

Wydaje się, że z podobnym problemem spotkali się również łacińscy translatorzy pism Orygenesa: Rufin z Akwilei i Hieronim ze Strydonu, którzy tłumacząc te terminy, posługiwali się różnymi ich odpowiednikami, głównie dwoma rzeczownikami: paenitentia ${ }^{23}$ oraz conversio ${ }^{24}$. Jednak ich znaczenia w stosunku do terminów greckich wydają się być nieco zawężone i jednoaspektowe. Wraz z upływem wieków w teologii termin paenitentia, tłumaczony początkowo jedynie jako żal, skrucha, pokuta, nawrócenie, zaczęto wiązać bardziej z aktem pokuty kościelnej, zadośćuczynieniem, karą oraz spowiedzią sakramentalną 25 . Podobnie i termin conversio, który od znaczenia: skrzywienie, zgięcie, zwrócenie się do kogoś, skrucha, nawrót, zmiana, obrót, odwrócenie przeszedł transformację $w$ kierunku nawrócenia rozumianego jako powrót do Boga, bądź - bardziej skrajnie - do wiary katolickiej, oraz zmianę dogłębną w życiu przejawiającą się np. wstapieniem do klasztoru ${ }^{26}$. Miało to swoje odzwierciedlenie $\mathrm{w}$ dotychczasowych badaniach dotyczących myśli wczesnochrześcijańskiej, a w sposób szczególny w poszukiwaniach w niej świadectw i źródeł istniejącej w owym czasie praktyki pokuty kościelnej bądź spowiedzi sakramentalnej. Mając na uwadze ogromny autorytet Scholarchy z Aleksandrii analizowano jego naukę z perspektywy chęci odnalezienia w niej przesłanek potwierdzających i teologicznie uzasadniających pokutę kanoniczną, jej formy oraz funkcje i zadania szafarzy. Taki sposób przedstawiania myśli Orygenesa dominuje w klasycznych dla dzisiejszych badaczy monografiach Daniélou $^{27}$ oraz Crouzela ${ }^{28}$. Inny nurt badań koncentrował się bardziej na tematyce grzechu, jego klasyfikacjach oraz sposobach oczyszczenia ${ }^{29}$. Tematyka

${ }^{23}$ Por. Origenes, In Leviticum hom. 1, 2, SCh 286, 72-74: „Iste autem «vitulus sine macula» vide, si non ille «saginatus» est «vitulus», quem pater pro regresso ac restituto sibi illo, qui perierat, filio, quique «omnem eius substantiam dilapidaverat», iugulavit et fecit convivium magnum et laetitiam habuit, ita ut «laetarentur angeli in coelo super uno peccatore poenitentiam agente»", PSP 31/2, 5.

${ }^{24}$ Por. tenże, In Numeros hom. VIII 1, 8, SCh 415, 214: „Conversio enim in praesenti vita et poenitentia fructuose gesta celerem conferet huiusmodi vulneribus medicinam, quia poenitentia non solum vulnus praeteritum sanat, sed et ultra animam peccato non sinit vulnerari”, PSP 34/1, 76-78; tenże, In Leviticum hom. 8, 11, SCh 287, 62: „In tria ergo purificationis huius, id est conversionis a peccato, ratio dividitur".

${ }^{25}$ Por. J. Sondel, Słownik łacińsko-polski dla prawników i historyków, Kraków 2001, 705; Plezia IV 8.

${ }^{26}$ Por. Plezia I 756-757.

${ }^{27}$ Por. J. Daniélou, Origène, Paris 1948.

${ }^{28}$ Por. Crouzel, Orygenes, s. 281-285.

${ }^{29}$ Por. J. Słomka, Oczyszczenie z grzechu w Homiliach Orygenesa o Księdze Kaptańskiej, 
pokutna zawiera się jednak fundamentalnie w nauce Orygenesa o metanoi, co w dalszej części artykułu postaramy się wykazać.

Ważne światło na zrozumienie metanoi rzuca Adamantios w 8. homilii do Księgi Kapłańskiej. Analizując praktyczne przepisy kapłańskie związane z problematyką trądu i chorób skóry nadaje im, podobnie jak wcześniej było w jahwizmie, znaczenie religijne oraz odnosi je do problematyki soteriologicznej. Oczyszczenie biblijne z trądu jest dla niego synonimem metanoi, która ma się dokonać w życiu człowieka, by mógł on cieszyć się radością szczęścia wiecznego. Opis różnego rodzaju trądu występującego na skórze ma znaczenie symboliczne i wskazuje na różnorakie kategorie grzechów, których człowiek może się dopuścić przebywając na tym świecie ${ }^{30}$. Uleczenie $\mathrm{z}$ nich nie jest jednak aktem jednostkowym i jednorodnym. Metanoia jest procesem uwarunkowanym z jednej strony zbawczą interwencją Boga, związaną z ofiarą Arcykapłana, z drugiej zaś materią grzechu oraz indywidualnym zaangażowaniem człowieka i jego wolą walki duchowej o uleczenie. Proces ten nie zamyka się jedynie do czasu przebywania na tym świecie, lecz ciężar popełnionych grzechów może sprawić, iż będzie on kontynuowany po śmierci. Widzimy tutaj pewne śladu hipotezy apokatastazy, jak również powoli kształtującej się w teologii i jeszcze nie w pełni wyartykułowanej nauki o czyśćcu ${ }^{31}$. Orygenes uważa, iż pewne grzechy są uleczone już teraz, lecz inne mogą tak mocno zapuścić swoje korzenie w duszy człowieka, iż w tym życiu nie jest on w stanie się od nich uwolnić, a przez to dostapić uleczenia i oczyszczenia. Przechodzą więc z nim do przyszłego życia i zostają poddane osądowi Arcykapłana, który orzeknie, czy ich choroba może zostać uleczona, czy też nie ${ }^{32}$. Może się jednak zdarzyć, iż zło tak mocno utkwiło w duszy, iż nie da się go usunąć, a zbawienna lecznicza terapia nie będzie możliwa ani w tym życiu, ani w przyszłym. Można w tym miejscu przywołać naukę o grzechach przeciwko Duchowi Świętemu, które według Ewangelii św. Mateusza $(12,31-32)$ nie będą odpuszczone ani w tym wieku, ani w przyszłym ${ }^{33}$. Bóg jednak jest większy niż grzech i hipotetycznie może dać człowiekowi nową szansę w kolejnych następujących po przyszłym wiekach czy światach. Nawrócenie to nie tylko uleczenie rany grzechu, lecz również usunięcie śladów dawnego zranienia. Niewiele jest bowiem ran, które zostają uleczone w taki sposób, że nie pozostał po nich żaden ślad. Bez całkowitego uzdrowienia, z blizny będącej śladem po dawnym grzechu może się

SSHT 38 (2005) z. 2, 337-353; S. Kaczmarek, Darowanie win. Orygenesowa egzegeza przypowieści o nielitościwym dlużniku (Mt 18, 23-25) i wezwania Modlitwy Pańskiej (Mt 6, 12; Łk 11, 4) wraz z jej uzupetnieniem (Mt 6, 14-15), Kraków 2005.

${ }^{30}$ Por. Origenes, In Leviticum hom. 8, 5, SCh 287, 24-32, PSP 31/2, 107-110.

${ }^{31}$ Por. K. Strzelecka, Czyściec, EK III 939-941.

${ }^{32}$ Por. Origenes, In Leviticum hom. 8, 5, SCh 287, 24-32, PSP 31/2, 107-110.

${ }^{33}$ Por. W. Turek, Grzech przeciwko Duchowi Świętemu w „,De principiis” Orygenesa, VoxP 17 (1997) t. 32-33, 77-88. 
rozwinąc nowa rana, a człowiek wróci do starego błędu ${ }^{34}$. Przedstawiona przez Adamantiosa analiza wskazuje, iż metanoia to nie jednorazowy akt, lecz ciagły proces przemiany i oczyszczenia, odejmujący nie tylko życie na tym świecie, lecz potencjalnie również życie przyszłe.

Orygenes nawiązując do sytuacji człowieka dotkniętego trądem grzechu podał swoją definicję nawrócenia. Rufin z Akwilei przekazał ją w sposób następujący:

„A zatem istota oczyszczenia, to znaczy nawrócenia się z grzechu, dzieli się na trzy części. Pierwszą z nich stanowi ofiara, przez którą są odpuszczane grzechy, drugą jest ta, dzięki której dusza zwraca się do Boga; trzecia symbolizuje płodność i owoce, które w pobożnych uczynkach objawia ten, kto się zwie nawróconym" 35 .

Powyższa definicja zakłada istniejącą w procesie metanoi wieloetapowość, zarówno na poziomie wewnętrznej przemiany człowieka, jak też zewnętrznej przynależności do wspólnoty odkupionych ${ }^{36}$.

1. Zbawcza ofiara Chrystusa. Pierwszym stadium metanoi przez które dokonuje się odpuszczenie grzechów jest ofiara (prima est hostia, qua peccata solvuntur) $)^{37}$. Złożył ją Jezus Chrystus, który będąc Stworzycielem, uniżył samego siebie. Zstępując na ziemię przyjął śmiertelne ciało i wziąwszy na siebie grzechy wszystkich stworzeń na krzyżu ofiarował własne życie za zbawienie świata ${ }^{38}$.

„Trąd grzechu bowiem nie może zostać oczyszczony bez udziału drzewa krzyża, [...] na którym, wedle słów apostoła Pawła, Zbawiciel «rozbroił Zwierzchności i Władze powiódłszy je w tryumfie na drzewie»"39.

Źródłem metanoi jest miłość Boga, przejawiająca się w odkupieniu człowieka na drzewie krzyża. Orygenes mówi o tym przy okazji prezentacji znaczenia ofiary kapłańskiej za grzech. Cielcem bez skazy, którego składa się na ołtarzu ofiarnym jako przebłaganie za grzechy, jest Jezus Chrystus. On czysty

\footnotetext{
${ }^{34}$ Por. Origenes, In Leviticum hom. 8, 5, SCh 287, 24-32, PSP 31/2, 107-110.

${ }^{35}$ Tamże 8, 11, SCh 287, 62: „In tria ergo purificationis huius, id est conversionis a peccato, ratio dividitur. Prima est hostia, qua peccata solvuntur; secunda est, qua anima convertitur ad Deum; tertia est fecunditatis et fructuum, quos in operibus pietatis is, qui dicitur conversus, ostendit", PSP $31 / 2,118$.

${ }^{36}$ Por. tamże.

${ }^{37}$ Tamże.

${ }^{38}$ Por. tenże, In Ezechielem hom. 1, 7, ed. M. Borret, SCh 352, 70-72, thum. S. Kalinkowski: Orygenes, Homilie o Księdze Ezechiela, ŹMT 16, Kraków 2000, 76-80; tenże, In Leviticum hom. 1, 3, SCh 286, 76-78, PSP 31/2, 6-7.

${ }^{39}$ Tenże, In Leviticum hom. 8, 10, SCh 287, 48: „Impossibile namque est sine «ligno» crucis peccati lepram posse purgari, nisi adhibeatur et «lignum», in quo Salvator, sicut Apostolus Paulus dicit, «exuit principatus et potestates, triumphans eos in ligno»", PSP 31/2, 114.
} 
i nieskalany przyjął na siebie grzechy rodzaju ludzkiego, by obmyć je swoją krwią $^{40}$. Człowiek uwikłany w grzech jak syn marnotrawny roztrwonił cały swój majątek żyjąc rozrzutnie i nie miał nic, co by mógł złożyć jako odkupienie za swoje życie z okazji powrotu do ojca ${ }^{41}$. Dzieło Chrystusa jest szczególne również dlatego, że On sam jest kapłanem i ofiarą, a krew Jego przelana na krzyżu w Jerozolimie swą zbawczą mocą sięgnęła w sposób duchowy świata niebiańskiego. Jezus został złożony w ofierze nie tylko za ludzi żyjących na ziemi, lecz również za istoty niebiańskie ${ }^{42}$. Jego ofiara nabiera przez to znaczenia uniwersalnego i ponadczasowego ${ }^{43}$. Z ofiary krzyża płyną zbawienne łaski, jak krew i woda, które wypłynęły z przebitego boku Jezusa ${ }^{44}$. Zatem to ofiara Chrystusa złożona Ojcu jest źródłem nawrócenia i oczyszczenia. Łaska metanoi wyraża się w Bożej ekonomii przez dwa aspekty. Z jednej strony Bóg oczyszcza człowieka z grzechu, w który on się uwikłał i który jest synonimem śmierci, z drugiej strony jest to darowanie grzesznikowi Chrystusa, z całym bogactwem darów, które On w sobie nosi. Ofiara Zbawiciela jest całkowicie darmowa. Tylko w niej człowiek może dostąpić łaski odpuszczenia grzechów i umocnienia na drodze metano ${ }^{45}$. W pierwszym rzędzie doświadcza się jej mocy w sakramencie chrztu świętego. Zanim jednak człowiek dostąpi jego łaski winien wejść na drogę przemiany. Rozpoczyna się ona od przejrzenia i zrozumienia, że został on oszukany przez szatana, a życie w grzechu i w służbie demonów prowadzi do śmierci. Nigdy nie jest za późno na odwrócenie się od błędu dawnego życia, zerwanie więzów zła i nowe narodzenie. Orygenes jednoznacznie wiąże metanoię z sakramentem chrztu oraz nadzieją zbawienia. Mówi o tym w sposób następujący:

„[...] przyjdź, aniele, podtrzymaj starca, który się nawrócił z dawnego błędu, odrzucił naukę demonów i «niegodziwość przemawiającą z wysokości», a podtrzymując go wspieraj i wspomagaj jak dobry lekarz: niemowlęciem jest starzec, on dzisiaj się urodził; niemowlęciem jest zgrzybiały starzec. A skoro go podtrzymasz, udziel mu «chrztu powtórnego narodzenia», przywołaj do siebie towarzyszy swej posługi, abyście wszyscy razem uczyli wiary tych, którzy niegdyś ulegli oszustwu. «Większa jest bowiem radość w niebie z jednego grzesznika, który się nawraca, niż z dziewięćdziesięciu dziewięciu sprawiedliwych, którzy nie potrzebują nawrócenia». Raduje się całe stworzenie, raduje się wraz z tymi, którzy mają dostapić zbawienia, i przyklaskuje

\footnotetext{
${ }^{40}$ Por. tamże 1, 3, SCh 286, 76-78, PSP 31/2, 6-7.

${ }^{41}$ Por. tamże 1, 2, SCh 286, 70-76, PSP 31/2, 4-6.

${ }^{42}$ Por. tamże 1, 3, SCh 286, 76-78, PSP 31/2, 6-7.

${ }^{43}$ Por. Słomka, Oczyszczenie z grzechu, s. 338.

${ }^{44}$ Por. Origenes, In Leviticum hom. 8, 10, SCh 287, 40-52, PSP 31/2, 112-115.

${ }^{45}$ Por. tamże 2, 4, SCh 286, 106-112, PSP 31/2, 16-19.
} 
im: albowiem «stworzenie z utęsknieniem oczekuje objawienia się synów Bożych»"46.

Chrzest jednak ani nie rozpoczyna ani nie kończy procesu metanoi. Nawrócenie podlega bowiem ciagłemu rozwojowi ${ }^{47}$. Chrystus przez sakrament dokonuje odradzającego obmycia. Jednakże na życiu człowieka ciążą skutki czy też ślady popełnionych wcześniej wykroczeń, które również potrzebują oczyszczenia. Chory uzdrowiony z trąqu ma ciagle na sobie brudne szaty, które należy uprać ${ }^{48}$. Jeżeli się w pełni nie oczyści, brud grzechu razem z nim przejdzie do przyszłego świata, gdzie jeszcze trudniej będzie go zmyć. Crouzel W swojej monografii omawiając tematykę pokuty, a w szczególności problematykę darowania grzechów rzekomo nieodpuszczalnych: bałwochwalstwa, cudzołóstwa i nierządu, wymienionych w Orygenesowym traktacie $O$ modlitwie, zwrócił uwagę na występujące u Scholarchy z Aleksandrii rozróżnienie na odpuszczenie i okupienie grzechów ${ }^{49}$. Według niego odpuszczenie (’̌́ $\varphi \varepsilon$ -

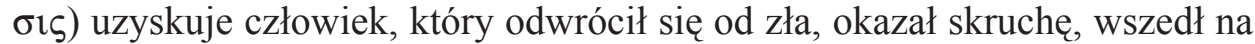
drogę nawrócenia i przyjął sakrament chrztu, przez co otrzymał oczyszczenie oraz nowe życie w Chrystusie. "A we i nie może być powtarzane przez kapłanów Kościoła ${ }^{50}$. Taką samą moc odpuszczenia ma jedynie chrzest krwi, ale o tym powiemy za chwilę. Kto jednak zgrzeszył po otrzymaniu wiary, przez skruchę i żal może uzyskać łaskę okupienia swych grzechów ( $\dot{\varepsilon} \tau \kappa \alpha \lambda \hat{\jmath} \pi \tau \omega)$, która jest drogą do ponownego odrodzenia. Zbawienna terapia po chrzcie może i powinna być kontynuowana, by wierzący stał się w pełni czysty ${ }^{51}$.

2. Ofiara czlowieka - okupienie grzechów. Orygenes w drugiej homilii do Księgi Kapłańskiej wylicza siedem ewangelicznych sposobów oczyszczenia $\mathrm{z}$ grzechów ${ }^{52}$. Pierwszym $\mathrm{z}$ nich jest wspomniany już wyżej sakrament chrztu. Chrzest wody gładzi dawne grzechy nie daje jednak gwarancji, co do świętości życia w przyszłości. Inaczej dzieje się za sprawą chrztu krwi, drugiego sposobu oczyszczenia. Przez męczeństwo wierzący jednoczy się z ofiarą Chrystusa, przyjmując za Niego śmierć ${ }^{53}$. Krew męczeństwa nie tylko obmywa z dawnych grzechów, lecz także usuwa ich skutki oraz niszczy grze-

\footnotetext{
${ }^{46}$ Tenże, In Ezechielem hom. 1, 7, SCh 352, 70-72, ŹMT 16, 85.

${ }^{47}$ Por. tenże, In Leviticum hom. 8, 11, SCh 287, 52-68, PSP 31/2, 115-119.

${ }^{48}$ Por. tamże.

${ }^{49}$ Por. Crouzel, Orygenes, s. 282-283.

${ }^{50}$ Por. Origenes, In Leviticum hom. 8, 10, SCh 287, 40-52, PSP 31/2, 112-115.

${ }^{51}$ Por. tamże 8, 11, SCh 287, 52-68, PSP 31/2, 115-119.

${ }^{52}$ Por. tamże 2, 4, SCh 286, 106-112, PSP 31/2, 16-19.

${ }^{53}$ Por. tenże In librum Iudicum hom. 7, 2, ed. P. Messié - L. Neyrand - M. Borret, SCh 389 , 174-182, tłum. S. Kalinkowski: Orygenes, Homilie o Księdze Sędziów, PSP 34/2, Warszawa 1986,
} 172-174. 
chy przyszłe ${ }^{54}$. Męczennik idzie prostą drogą za swoim Mistrzem do ołtarza Bożego, gdzie przebywają święci i błogosławieni, a żadna moc zła nie jest w stanie mu przeszkodzić czy przy sądzie cokolwiek zarzucić. Pozostałe cztery sposoby mają moc okupienia grzechów ( $\dot{\varepsilon} \pi$ เ $\alpha \lambda \hat{v} \pi \tau \omega)$, lecz nie dotyczą sensu stricto pokuty kościelnej. Trzecim sposobem jest udzielanie jałmużny; czwartym - umiejętność darowania win oraz przebaczenie; piątym - troska o zbawienie innych przejawiająca się w nawracaniu grzeszników (conversio); szóstym - pełnia miłości, która podobnie jak w przypadku ewangelicznej jawnogrzesznicy namaszczającej nogi Jezusa zakrywa wiele grzechów ${ }^{55}$. Ostatnim sposobem wspomnianym przez Adamantiosa jest pokuta (paenitentia). Nie jest zamierzeniem niniejszej pracy szczegółowe opracowanie problematyki pokuty kościelnej, dlatego też zostaną podjęte przez nas jedynie te jej aspekty, które dają teologiczne uzasadnienie traktowania jej jako kolejnego etapu w całościowym procesie metanoi. Pokuta - jak dowodzi Orygenes jest to sposób trudny i wymagający dużego wysiłku (dura et laboriosa) ${ }^{56}$. Można w nim wyróżnić dwa wymiary: wewnętrzny i zewnętrzny. Pierwszy z nich jest związany z duchowym nastawieniem człowieka wierzącego, który świadom popełnionego zła cierpi z powodu wcześniejszych własnych upadków. Rodzi to poczucie prawdziwego żalu, wyrzuty sumienia, skruchę oraz łzy. Wewnętrzna postawa nawrócenia prowadzi do uznania własnej winy oraz potrzebę restytucji. W związku z tym grzesznik oddaje się w zaufaniu w ręce Kościoła, by publicznie wyznać własne ciężkie winy oraz przyjać nałożoną przez biskupa, bądź wyznaczonego przez niego prezbitera, kościelną pokutę (wymiar zewnętrzny). Ma być ona nie tyle karą za popełniony grzech, co lekarstwem, które pozwoli wyrwać się z jego więzów, oczyścić i żyć w świętości ${ }^{57}$. Orygenes przywołuje w tym miejscu obraz trędowatego, któremu należy rozedrzeć szaty i odsłonić głowę. Według niego ten kto ma „trędowatą duszę" i jest przygnieciony grzechami nie powinien zakrywać swej brzydoty przed innymi, chowając nagość za słowami samousprawiedliwienia i wymówkami. Prawda o grzechu jest trudna, lecz wyzwalająca. Dlatego też grzesznik z odsłoniętą głową i obnażony staje w prawdzie przed wspólnotą wierzących, pokazuje trąd swoich wykroczeń przeciwko Bogu, aby dzięki naganie, nauce i wstawiennictwu Kościoła poprawić się, okupić grzech i zasłużyć na przebaczenie $^{58}$. W tym akcie przejawia się wiara w Chrystusa i Jego zbawienną ofiarę oraz zaufanie Kościołowi.

Człowiek według Orygenesa otrzymał od Boga przeogromne bogactwo darów, które nigdy do niego nie należały, ale zostały mu powierzone w depo-

\footnotetext{
${ }^{54}$ Por. tamże.

${ }^{55}$ Por. tenże, In Leviticum hom. 2, 4, SCh 286, 106-112, PSP 31/2, 16-19.

${ }^{56}$ Por. tamże.

${ }^{57}$ Por. tamże.

${ }^{58}$ Por. tamże 8,10 , SCh 287, 40-52, PSP 31/2, 112-115.
} 
zyt. Darem takim jest przede wszystkim sam Bóg oraz Logos-Chrystus, w którym są ,ukryte wszelkie skarby mądrości i wiedzy" 59 , dalej - sakramentalne obmycie w wodach chrztu, jak też słowo prawdy. Grzech jest zlekceważeniem Bożych darów, a w przypadku herezji niejako kradzieżą tego, co jest święte. By zadośćuczynić za winy grzesznik ma nie tylko zwrócić z należytym procentem bezprawnie zagarnięte dobra, lecz również złożyć dodatkową ofiarę „o wartości świętego sykla" ${ }^{00}$. Orygenes zdaje się uważać, iż podobnie jak w Starym Testamencie nie wolno było kapłanom Prawa składać ofiar za szczególnie ciężkie grzechy, aby zostały odpuszczone, tak również w niektórych przypadkach nie wystarczy tylko sama modlitwa kapłanów Kościoła, by nastapiło darowanie winy ${ }^{61}$. Scholarcha z Aleksandrii krytykuje w tym miejscu postawę niektórych kapłanów i zarzuca im nawet ignorancję teologiczna, gdy zaczynają sobie rościć prawo do odpuszczania za pomocą modlitwy ciężkich grzechów: bałwochwalstwa, cudzołóstwa i nierząau ${ }^{62}$. Chrześcijanin, który nosi na sobie piętno ciężkich grzechów winien oddać się w pokorze w ręce Kościoła, który będzie go od tej pory wspierał swoją modlitwą i odkrywał przed nim drogę pokuty i odrodzenia. Pokuta kościelna jest jednak związana z osobistą ofiarą grzesznika. Omawiając przepisy rytualne z Księgi Kapłańskiej i składane ofiary za grzech względem rzeczy poświęconych i należących do Boga, Orygenes mówi, że okupieniem winy będzie nie tylko zwrot tego, co grzesznik zagarnął, ale również ofiarowanie baranka zadośćuczynienia. Są bowiem winy, które mogą być odpuszczone jedynie za taką cenę. Tylko baranek bez skazy ofiarowany Bogu i modlitwa przebłagania sprawowana przez kapłanów mają moc odpuszczenia grzechu ${ }^{63}$. Symbol baranka nawiązuje oczywiście do Chrystusa i Jego zbawczej ofiary. Podobnie jak kiedyś baranek został zabity w miejsce Izaaka, tak i teraz krew Chrystusa ma moc obmycia z grzechów. By złożyć taką ofiarę grzesznik musi kupić owego baranka za cenę ,świętego sykla". Sykl, według Adamantiosa, jest symbolem pieniądza Bożego. Nie należy on do bogactw tego świata, takich jak złoto, srebro czy drogocenne przedmioty. Bogactwa tego świata są bowiem nietrwałe i nie należą do nas, a mogą być jedynie nam powierzone. Świętym syklem jest rzetelna i szczera wiara, bez domieszki błędów wynikających z heretyckich poglądów, zakorzeniona w Chrystusie, który jest źródłem mądrości i wiedzy. On jest jak nasz własny skarbiec, z którego możemy czerpać pieniądze na ofiarę miłą Bogu za własne grzechy.

Monety funkcjonujące w powszechnym obiegu mogą być prawdziwe albo fałszywe. Człowiek winien w życiu nauczyć się je rozróżniać. Podobnie jest

\footnotetext{
${ }^{59}$ Tamże 3, 8, SCh 286, 152-160, PSP 31/2, 32-35.

${ }^{60}$ Tamże 3, 6, SCh 286, 144-148, PSP 31/2, 30-31.

${ }^{61}$ Por. tenże, De oratione 28, 9, GCS 3, 380-381, thum. Kania - Pietras, s. 209-210.

${ }^{62}$ Por. tamże 28, 10, GCS 3, 381, thum. Kania - Pietras, s. 210.

${ }^{63}$ Por. tenże, In Leviticum hom. 3, 6, SCh 286, 144-148, PSP 31/2, 30-31.
} 
i w kwestii pieniądza, za który można kupić nieskalanego baranka na okupienie grzechów. Fałszywym jest ten pieniądz, który chociaż posiada podobiznę prawdziwego króla, został jednak wybity poza mennicą Kościoła i nie zawiera prawdziwej królewskiej pieczęci. Takie bogactwo poznania, czyli fałszywy sykl, oferują heretycy. Chociaż mają wyryte na swych monetach imię Chrystusa, to jednak ich pieniądz jest bezwartościowy. Grzesznik mając ich bogactwa, jest obiektywnie biedny i oszukany, a za monety heretyków nie kupi baranka, którego krew jest w stanie obmyć go z grzechów ${ }^{64}$.

Pokuta kościelna nie jest więc tylko zewnętrznym, jurydycznym aktem skruchy czy próbą zadośćuczynienia Bogu przez nakazane przez Kościół praktyki pokutne takie jak: płacz, posty oraz wszelka wstrzemięźliwośćc5. Nawrócenie wyrażające się przez pokutę kościelną jest wewnętrznym oddaniem swego życia Chrystusowi oraz odniesieniem do Boga tego wszystkiego, co jest historią człowieka. Zwrócenie przez pokutę Bogu rzeczy świętych, to przede wszystkim powierzenie mu życia w wymiarze zewnętrznym, jak i wewnętrznym. To, co do tej pory człowiek marnotrawił przez wszelkie świeckie działania niezgodne $\mathrm{z}$ wolą Bożą, przez proces nawrócenia nabiera nowego wymiaru. Orygenes nawiązuje tutaj do nauki o pięciu zmysłach, kojarzonych $\mathrm{z}$ cielesnością i pożądliwością, które od tej pory mogą być na nowo ukierunkowane na prawdziwe wartości, a człowiek odrodzony wewnętrznie otrzyma czyste serce i zdolność ostatecznego oglądania Boga ${ }^{66}$.

Podsumowując możemy powiedzieć, iż proces metanoi zakorzeniony w ofierze zbawczej Chrystusa zakłada na nowo zwrócenie się ku Niemu przez wiarę, by z powrotem otrzymać od Niego prawdziwe bogactwo poznania, mądrości i łaski. Mimo, iż Orygenes wymienia siedem sposobów oczyszczenia z grzechów, to należy je potraktować alegorycznie i zobaczyć w nich nowy sposób życia chrześcijanina w duchu Ewangelii. Siódemka jest dla Orygenesa liczbą świętą oraz zapowiada odnowioną rzeczywistość życia człowieka, który będąc jeszcze na ziemi, może uczestniczyć w chwale nieba i z czystym sercem oglądać Boga ${ }^{67}$.

3. Płodność i owoce nawrócenia. Proces metanoi, mimo, iż fundamentalnie jest związany z rzeczywistością duchową i dokonuje się w sercu człowieka, ma jednak charakter społeczny oraz jest ukierunkowany na wspólnotę Kościoła. Adamantios zdaje sobie sprawę ze słabości natury ludzkiej i jej skłonności do grzechu. Dlatego też kolejnym etapem w procesie metanoi jest zwrócenie się chrześcijanina ku wspólnocie wierzących, by trwając w niej wydać święte

${ }^{64}$ Por. tamże 3, 8, SCh 286, 152-160, PSP 31/2, 32-35.

${ }^{65}$ Por. tamże 2, 4, SCh 286, 106-112, PSP 31/2, 16-19.

${ }^{66}$ Por. tamże 3, 6, SCh 286, 144-148, PSP 31/2, 30-31; zob. M. Szram, Duchowy sens liczb w alegorycznej egzegezie aleksandryjskiej (II-V w.), Lublin 2001, 132.

${ }^{67}$ Por. Origenes, In Leviticum hom. 3, 7, SCh 286, 148-150, PSP 31/2, 31-32; zob. Szram, Duchowy sens liczb, s. 136. 
owoce nawrócenia. Aby mogło się to urzeczywistnić, konieczne jest umocnienie nawróconego grzesznika. Dokonuje się ono w pierwszym rzędzie przez posługę słowa. Chrystus, sam będąc Nauczycielem, dał Kościołowi urząd kapłański, aby powołani do tej posługi, na wzór Wiecznego Kapłana, byli nauczycielami prawdziwej wiary i szafarzami miłosierdzia ${ }^{68}$. Chrześcijanin na tym etapie metanoi w słowie prawdy znajdzie drogę, która wprowadzi go do wspólnoty ze świętymi. Umocnienie nawracającego się grzesznika dokonuje się również przez specjalną modlitwę wstawienniczą kapłana. Orygenes nawiązuje w tym kontekście do Listu apostoła Jakuba i zawartego w nim zalecenia dotyczącego chorych. Według Adamantiosa tekst mówiący o wezwaniu kapłanów Kościoła, którzy kolegialnie, w imieniu Pana, wkładają na chorego ręce namaszczone oliwą i modlą się z wiarą, należy odnieść do pokutującego grzesznika ${ }^{69}$. Być może w sprawowanym w owym czasie obrzędzie pokuty kanonicznej występował akt namaszczenia świętym olejem. Na taką formę kończącą niejako kanoniczną pokutę wskazywałby tekst z Księgi Kapłańskiej mówiący o finalnym oczyszczeniu trędowatego. Znajduje się tam zalecenie, aby kapłan składając ofiarę za oczyszczenie nalał na dłoń oliwę i siedem razy dokonał przed Panem pokropienia, później zaś namaścił oczyszczającego się. Według Scholarchy z Aleksandrii oliwa symbolizuje łaski Ducha Swiętego. Kapłan namaszcza grzesznika, aby go umocnić i udziela mu siedmiorakiej mocy Ducha Świętego, by mógł on na nowo dostapić radości zbawienia ${ }^{70}$. Podobnie jak serce grzesznika owładnięte jest siedmioma duchami nieczystymi, tak przez siedmiokrotne strząśnięcie oliwy przed Panem dokonuje się wypędzenie siedmiu duchów zła, aby serce było czyste i gotowe na przyjęcie Ducha Pana. Dar Ducha został przez Orygenesa przyrównany do „szaty i pierścienia", które z powrotem otrzymał od ojca powracający skruszony syn marnotrawny ${ }^{71}$. Chrześcijanin, któremu za sprawą Zbawiciela na nowo została przywrócona godność syna, ma wydać w swoim życiu święte owoce i plony nawrócenia. Jednym z podstawowych jest dusza zwrócona do Boga przez modlitwę. Dar Ducha Świętego, który na nowo został udzielony oczyszczającemu się grzesznikowi, uzdalnia go do pełnej ufności modlitwy. Modlitwa jest bowiem przywilejem społeczności świętych oraz tych, którzy weszli na drogę metanoi. Zdaniem Orygenesa Bóg nie wysłuchuje tych, którzy żyją w grzechu, chociaż mogą oni znać słowa chociażby Modlitwy Pańskiej i je wymawiać. $Z$ pewnością Scholarcha miał tu na uwadze nie tylko upadłych chrześcijan, ale również gnostyków, którzy podważali sens modlitwy uważając, że Bóg i tak wie, czego człowiekowi naprawdę potrzeba i każdemu, niezależnie od jego wysiłku, przeznaczył z góry inny los, darując zbawienie bądź odrzu-

\footnotetext{
${ }^{68}$ Por. Origenes, In Leviticum hom. 5, 3, SCh 286, 214-222, PSP 31/2, 54-57.

${ }^{69}$ Por. tamże 2, 4, SCh 286, 106-112, PSP 31/2, 16-19.

${ }^{70}$ Por. tamże 8, 11, SCh 287, 52-68, PSP 31/2, 115-119.

${ }^{71}$ Por. tamże.
} 
cając na wieki. Zwyczajna modlitwa była więc wśród gnostyków odrzucana, a słowa Biblii mówiące o modlitwie komentowano w sobie właściwym kluczu znaczeniowym $^{72}$. Omawiając Modlitwę Pańską i zawartą w niej prośbę o odpuszczenie win Adamantios postawił pytanie: kogo więc Bóg wysłuchuje? Po przeprowadzonym toku dowodzenia dał odpowiedź:

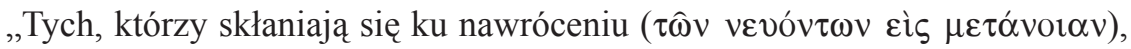
chociaż jeszcze nie przestali być grzesznikami ( $\left.\left.\alpha \mu \alpha \rho \tau \omega \lambda o^{\prime}\right)\right)^{\prime \prime 73}$.

Szczególnego znaczenia nabiera w tym kontekście według Aleksandryjczyka Modlitwa Pańska. Metanoia wyraża się w niej przez żal, uznanie własnej winy oraz błaganie o miłosierdzie ${ }^{74}$. W niej to grzesznik prosi Boga o łaskę zmiłowania, ale i sam daje dowód swego nawrócenia, naśladując Boga w umiejętności darowania win tym, którzy zawinili względem niego.

Podobna myśl dominuje w Orygenesowym komentarzu do przypowieści o nielitościwym dłużniku (Mt 18, 23-35). Metanoia chrześcijanina to ciągła świadomość, że jest się względem Boga, jak wielki dłużnik nad którym Pan się ulitował. Dłużnik czując niesprawiedliwość, której się dopuścił, prosi o litość i wyraża gotowość późniejszego zwrotu oraz wynagrodzenia krzywdy. Darowanie grzechów przez Boga zobowiązuje chrześcijanina do późniejszego postępowania zgodnie z logiką miłosierdzia. Gdy więc winowajcy okazują względem chrześcijanina żal i skruchę, winien on być łagodny i kierować się obowiązkiem odpuszczenia winy żałującemu bratu ${ }^{75}$. Również wobec człowieka zaślepionego przez zło i nie okazującego skruchy chrześcijanin będący na drodze metanoi winien postępować z należną mu łagodnością. Mając na uwadze jego zbawienie powinien go upomnieć i zrobić wszystko dla sprowadzenia go z drogi, na której przez grzech sam sobie szkodzi, nie nosząc jednak względem niego w swoim sercu żadnej urazy ${ }^{76}$.

Przez słuchanie Słowa i modlitwę człowiek dostępuje łaski coraz lepszego poznania Boga, co owocuje w udoskonalającej się ciągle miłości. Metanoia umożliwia bowiem zmianę wewnętrzną człowieka, który od tego, co ziemskie i co stanowi wartość tego świata, przechodzi ku temu, co niebieskie, ciagle wznosząc się ku Bogu. Taki człowiek staje się coraz bardziej doskonały, a wypełniając przykazania buduje jedność z Bogiem i braćmi. Jego otwarcie na Prawdę pozwala zbadać co jest dobre, a co złe, i w konsekwencji wybierać jedynie to, co ma dla niego zbawienną korzyśćc ${ }^{77}$. Poznanie Boga stanowi dla

${ }^{72}$ Por. Origenes, De oratione 5, 1, GCS 3, 308, thum. Kania - Pietras, s. 115.

${ }^{73}$ Origenes, Fragmenta in Ioannem 70, ed. E. Preuschen, GCS 10, 538, thum. S. Kalinkowski:

Orygenes, Komentarz do Ewangelii wedhug św. Jana, ŹMT 27, Kraków 2003, 610.

${ }^{74}$ Por. Kaczmarek, Darowanie win, s. 247.

${ }^{75}$ Por. tamże, s. 66.

${ }^{76}$ Por. tamże, s. 68-69.

${ }^{77}$ Por. Origenes, In Exodum hom. 10, 4, ed. M. Borret, SCh 321, 310-312, thum. S. Kalinkowski: Orygenes, Homilie o Księdze Wyjścia, PSP 31/1, Warszawa 1984, 248-249. 
człowieka będącego na drodze metanoi fundament do naśladowania ( $\mu$ í $\eta\rceil \varsigma \varsigma)$, czyli podstawę w procesie upodobnienia się do Chrystusa. Świadomość własnej grzeszności oraz chęć okupienia win przez ofiarę rodzi dobro, które przejawia się w wypełnianiu woli Bożej. W tym kontekście wymienione przez nas wcześniej sposoby oczyszczenia z grzechów nabierają znaczenia symbolicznego, gdyż oznaczają one pełnię miłości człowieka, który chce swoje życie złożyć Bogu w ofierze, podobnie jak to uczynił Chrystus ${ }^{78}$.

Droga metanoi nie kończy się na naszym świecie. Według Orygenesa proces udoskonalenia i oczyszczenia może być hipotetycznie kontynuowany w kolejnych wiekach czy światach następujących po naszym. Człowiek duchowy posiądzie w nich jeszcze większą doskonałość, ten zaś, kto niesie na sobie piętno winy, będzie musiał przejść przez oczyszczający ogień Bożej miłości. Grzesznicy w tym procesie nie są zostawieni sami sobie, lecz posiadają ciągłe wsparcie tych, którzy osiągnęli już chwałę zbawienia. Niebo bowiem nie będzie w pełni doskonałe i szczęśliwe, gdy zabraknie w nim tych, którzy pierwotnie zostali do niego powołani. Zarówno święty Arcykapłan, jak i archaniołowie, aniołowie oraz święci zanoszą swoje modlitwy do Boga i wspierają swych braci na ziemi, aby dostapili chwały wiecznej:

„[...] stąd w niebie cieszą się więcej $\mathrm{z}$ «jednego nawróconego grzesznika niż z dziewięćdziesięciu dziewięciu sprawiedliwych, którzy nie potrzebują nawrócenia»" $"$.

\section{THE JOY FROM THE CONVERTED SINNER. METANOIA IN THE TEACHING OF ORIGEN}

\section{(Summary)}

In this article the subject of metanoia was presented and the joy from converted sinner in the teaching of Origen in the context of parable "the lost sheep" according the Gospel of St. Luke in chapter 15. At the foundation of the Origen's analysis there were the problems of salvation history and eschatology connected with the apocatastatis hypothesis. The return of the primitive community will be the source of perfect joy both for the fallen human-beings (because of their sins) and for those who persisted in God's love. Metanoia is the process connected with beneficial intervention of God in the human history. The first stage of metanoia, by which there is the absolvation of sins, is the sacrifice which Jesus Christ offered on the cross. Man receiving God's love should turn his attention towards God once again, recompense for his sins and give the holy fruits of convertion. The process of metanoia is not only closed during the life in this world but is still going on after our death.

\footnotetext{
${ }^{78}$ Por. Origenes, In Leviticum hom. 2, 4, SCh 286, 106-112, PSP 31/2, 16-19.

${ }^{79}$ Tenże, De oratione 11, 1, GCS 3, 321, thum. Kania - Pietras, s. 132-133.
} 